\title{
PENDIDIKAN KARAKTER KEWIRAUSAHAAN DI SEKOLAH MENEGAH KEJURUAN UNTUK MENINGKATKAN MINAT BERWIRAUSAHA DI SMK NEGERI 1 SAKRA
}

\author{
Hermany \\ SMK Negeri 1 Sakra \\ hermanysmkn1sakra@gmail.com
}

\begin{abstract}
The superiority of the Vocational High School compared to other middle schools is that the students are trained to become entrepreneurs. The education model that is always developed in vocational schools to conduct entrepreneurship education is a model of entrepreneurship character education. The purpose of this study was to obtain an appropriate educational model for implementing entrepreneurship character education in SMKs to explore the experience of SMK students in implementing Character models in entrepreneurship learning. The focus of research on how students internalize character values, aspects of soft skills and transferable skills in learning Entrepreneurship so that students are interested in entrepreneurship, the research approach is qualitative phenomenological. A research orientation to understand, explore, and interpret the meaning of events, phenomena and relationships with people naturally in certain situations, during the entrepreneurial learning process. Data collected through observation, interviews and documentation are described as is. Opinions of students, educators, behavior, attitudes, interests, skills, weaknesses, are an important part of providing input to the improvement of entrepreneurial learning. The findings show that the enthusiasm of students is high, indicated by activities in five stages, the entrepreneurship project starts from (1) Small groups, (2) Exploration, (3) Development of business ideas, (4) Preparation and Presentation of business plans, (5) Action and business competition, running smoothly and successfully internalizing 3 character values and 5 soft skills-transferable skills with a high score of $68 \%$ and a moderate score of $32 \%$. All products are sold out and some products have received orders, this shows an indication of growing entrepreneurial interest.
\end{abstract}

Keywords : Educational Model, SMK Entrepreneurship Character, Soft SkillsTransferable Skills

\footnotetext{
Abstrak: Keunggulan Sekolah Menengah Kejuruan dibandingkan sekolah meneggah yan lainnya yakni peserta didiknya di bina untuk berwirausaha. Model pendidikan yang selalu dikembangkaan di SMK untuk melakukan pendidikan kewirausahaan adalah model pendidikan karakter kewirausahaan. Tujuan penelitian ini adalah untuk mendapatkan model pendidikan yang sesuai untuk melaksanakan pendidikan karakter kewirausahaan di SMK. Untuk mengeksplorasi pengalaman peserta didik SMK dalam

Fondatia : Jurnal Pendidikan Dasar

Volume 3, Nomor 2, September 2019; 59-73

https://ejournal.stitpn.ac.id/index.php/fondatia
} 
mengimplementasikan model Karakter dalam pembelajaran kewirausahaan. Fokus penelitian pada bagaimana peserta didik menginternalisasi nilai-nilai karakter, aspek soft skills dan transferable skills dalam pembelajaran Kewirausahaan sehingga peserta didik berminat untuk berwirausaha, Pendekatan penelitian adalah kualitatif fenomenologis. Orientasi penelitian untuk memahami, menggali, dan menafsirkan arti dari peristiwa-peristiwa, fenomena-fenomena dan hubungan dengan orang-orang secara alamiah dalam situasi tertentu, selama proses pembelajaran kewirausahaan. Data terkumpul melalui pengamatan, wawancara dan dokumentasi dideskripsikan apa adanya. Pendapat peserta didik, pendidik, perilaku, sikap, minat, keterampilan, kelemahan, merupakan bagian yang penting untuk memberikan masukan terhadap perbaikan pembelajaran kewirausahaan. Temuan menunjukkan bahwa antusiasme peserta didik tinggi, ditunjukkan dengan aktivitas dalam lima tahapan, project kewirausahaan dimulai dari (1) Grup (kelompok) kecil, (2) Eksplorasi, (3) Pengembangan ide usaha, (4) Penyusunan dan Presentasi rencana usaha, (5) Aksi dan Kompetisi usaha, berjalan dengan lancar dan berhasil meng internalisasi 3 nilai karakter dan 5 soft skills-transferable skills dengan skor tinggi sebanyak 68\% dan skor sedang $32 \%$. Semua produk terjual habis dan beberapa produk sudah menerima pesanan, hal ini menunjukkan indikasi tumbuhnya minat berwirausaha.

Kata Kunci: Model Pendidikan, Karakter Kewirausahaan SMK, Soft SkillsTransferable Skills

\section{PENDAHULUAN}

Sekolah Menengah Kejuruan (SMK) sebagai penghasil tenaga kerja perlu memperhatikan keunggulan komparatif, kompetetif, maupun kemampuan bekerjasama bagi para peserta didik. Keunggulan komparatif merupakan kemampuan dalam menghasilkan barang/jasa dengan biaya yang lebih efisien, sedangkan keunggulan kompetitif merupakan kemampuan daya saing lulusan SMK dalam tawar menawar. Oleh karena itu SMK perlu mengupayakan agar lulusannya mampu dalam mendapatkan pekerjaan atau menciptakan lapangan kerja, dan mampu bersaing di lapangan kerja. Dengan kemampuan lulusan SMK untuk menciptakan lapangan kerja maupun kemampuan bersaing untuk mendapatkan pekerjaan maka diharapkan dapat mengurangi tingkat pengangguran di Indonesia yang masih Tinggi.

Pembangunan karakter dan budaya termasuk karakter dan budaya kewirausahaan di SMK telah kembali ditekankan oleh Pemerintah melalui UndangUndang No 17 tahun 2007 tentang Rencana Pembangunan Jangka Panjang Nasional (RPJPN) tahun 2005-2025, dimana pendidikan karakter ditempatkan sebagai landasan 
untuk mewujudkan visi pembangunan Nasional, yaitu "mewujudkan masyarakat berakhlak mulia, bermoral, beretika, berbudaya dan beradab berdasarkan Pancasila" 1 .

Secara Filosfis, pendidikan karakter sebenarnya sudah ditanamkan olh $\mathrm{Ki}$ Hajar Dewantara. Di dalam konsep pendidikannya, beliau berpendapat bahwa pendidikan adalah daya upya untuk memajukan bertumbuhnya budi pekerti (kekuatan bathin, karakter), pikiran, dan tubuh anak ${ }^{2}$. Pendidikan karakter kewirausahaan juga sesuai dengan teori pendidikan karakter dari Kementrian Pendidikan Nasional RI. Pada Kontek Mikro, pendidikan karakter berpusat pada satuan pendidikan formal dan non formal secara holistik ${ }^{3}$.

Program aksi pendidikan berbasis soft skills yang dilaksanakan Kementerian Pendidikan dan Kebudayaan (Kemendikbud) Indonesia sejak tahun 2005, dengan tema "SMK Pasti Bisa" kemudian diikuti dengan program "Pendidikan Karakter" dalam implementasinya menghadapi kendala-kendala. Pendidik yang sebelumnya hanya dituntut melatihkan soft skills, kini harus mengintegrasikan pendidikan karakter dalam proses pembelajaran ${ }^{4}$.

Namun demikian, dalam pembelajaran Kewirausahaan cara-cara menentukan nilai-nilai karakter dan aspek soft skills maupun transferable skills apa yang perlu diinternalisasikan, belum ada standar baku, sehingga menyebabkan banyak pendidik mengalami kesulitan. Permasalahan ini diperkuat oleh temuan menunjukkan bahwa cara cara menginternalisasi nilai-nilai karakter kedalam setiap mata pelajaran sampai saat ini belum ada prosedur. Dalam menginternalisasikan nilai-nilai moral religius setiap pendidik memiliki cara atau strategi yang berbeda-beda. Perbedaan disebabkan karena belum jelasnya nilai-nilai moral religius yang hendak ditanamkan dalam proses pembelajaran. Artinya, belum ada common values (nilai-nilai umum yang disepakati bersama) untuk diimplemen- tasikan dalam proses pembelajaran di kelas.

\footnotetext{
${ }^{1}$ Endang Mulyani, dkk. Pengembangan Pendidikan Kewirausahaan, (Jakarta: Pusat Kurikulum, Badan Penelitian dan Pengembangan, Kementrian Pendidikan Nasional, 2010) hlm. 8.

${ }^{2}$ Samani Muhlas \& Hariyanto, Konsep dan Model Pendidikan Karaakter. (Bandung: Rosdakarya 2011) hlm: 33

${ }^{3}$ Muhammad Nuh, Desain Induk Pendidikan Karakter kementrian Pendidikan Nasional. (Jakarta: Kementrian Pendidikan Nasional. 2010), hlm. 26

${ }^{4}$ Hidayatullah, Pendidikan karakter: membangun peradaban bangsa. (Surakarta: Yuma Pustaka. 2010), hlm. 12
} 
Aspek-aspek soft skills dan transferable skills yang paling diperlukan dan penting untuk diinternalisasikan dalam pembelajaran kewirausahaan di SMK yaitu: administration skill, change skill, customer service skill, problem solving skills, counseling skills, sementara nilai-nilai karakternya adalah: berani, respect dan sportif. Model pembelajaran kewirausahaan yang dapat menginternalisasikan soft skills, transferable skills dan nilai-nilai karakter tersebut adalah dengan melalui lima tahapan, dimulai dari tahap: (1) pembentukan kelompok kecil; (2) eksplorasi yang dilakukan di dalam maupun di luar kelas; (3) pengembangan ide usaha; (4) penyusunan dan presentasi rencana usaha; dan (5) pelaksanaan dan kompetisi usaha.

Nilai-nilai Karakter sifat karakter sebagai suatu watak yang bersifat tetap. Sekali terbentuk, karakter akan bertahan lama. Sementara itu, karakter sebagai kualitas mental atau moral, akhlak atau budi pekerti seseorang yang merupakan kepribadian khusus yang menjadi penggerak seseorang melakukan sesuatu. kualitas karakter meliputi sembilan pilar, yaitu: (1) cinta Tuhan dan segenap ciptaanNya, (2) tanggung jawab, disiplin dan mandiri, (3) jujur/amanah dan arif, (4) hormat dan santun, (5) dermawan, suka menolong, dan gotong-royong, (6) percaya diri, kreatif dan pekerja keras, (7) kepemimpinan dan adil, (8) baik dan rendah hati, (9) toleran, cinta damai dan kesatuan. Dengan demikian, orang yang memiliki karakter baik adalah orang yang memiliki kesembilan pilar karakter tersebut.

Transferable skills sebagai keterampilan yang dapat ditransfer di tempat kerja untuk menyelesaikan pekerjaan. Cara yang paling efektif untuk mentransfer skills adalah dengan mengikutsertakan peserta didik untuk melakukan tahapan pekerjaan dan mempraktikkan tahapan pekerjaan tersebut dalam konteks pelatihan lapangan dan melakukan pengulangan. Praktek merupakan kunci utama bagi seseorang untuk mengakuisisi skills yang baru. Atribut penting transferable skills yang digunakan dalam dunia kerja, yaitu sebagai berikut: (1) komunikasi verb, (2) komunikasi nonverbal, (3) menulis laporan, (4) bekerja dengan orang lain, (5) bekerja dengan teknologi dan informasi, (6) menganalisis masalah, (7) me mecahkan masalah, dan (8) berorganisasi. Soft skills adalah seperangkat kemampuan yang mempengaruhi bagaimana manusia berinteraksi dengan orang lain. Definisi ini menunjukkan bahwa terdapat beberapa atribut soft skills yang merupakan atribut transferable skills. 
Dalam proses pembelajaran memasukkan unsur mengamati, menanya, mengumpulkan data, mengasosiasi dan mengkomunikasikan sesuai penerapannya pada fase-fase: (1) pembentukan kelompok kecil (small group building), (2) eksplorasi kewirausahaan (entrepreneur exploration), (3) pengembangan ide usaha (idea development), (4) penyusunan dan presentasi rencana usaha (preparing and presentation business plan), dan (5) pelaksanaan dan kompetisi usaha (action and business competitions).

\section{METODE PENELITIAN}

Qualitatif Fenomenologi research dipilih sebagai pendekatan penelitian ini. Orientasi penelitian fenomenologi, untuk memahami, menggali, dan menafsirkan makna dari peristiwa-peristiwa, fenomena-fenomena dan hubungan dengan para peserta didik secara alamiah dalam situasi pembelajaran kewirausahaan. Pengamatan terlibat (participant observation) terhadap fenomena sosial secara alamiah dan wawancara secara mendalam (dept interview) digunakan sebagai sumber data. Triangulasi sumber dan metode digunakan untuk menguji validitas data. Teknik analisis data menggunakan model analisis interaktif ${ }^{5}$.

Purposive dan snow ball sampling di- gunakan dalam menyeleksi dan memilih subjek penelitian yang dilakukan di SMKN 1 Sakra. Peserta didik dan pendidik Bidang studi Pemasaran yang mempelajari mata pelajaran Prakarya dan Kewirausahaan dipilih sebagai subjek penelitian (partisipan). Partisi pan dalam penelitian ini terdiri dari dua pendidik mata pelajaran Prakarya dan Kewirausahaan di kelas 12, yang terdiri dari satu pendidik Bidang Studi dan satu pendidik bantu, serta para peserta didik yang berjumlah tiga puluh satu (31) peserta didik.

Teknik pengumpulan data dalam penelitian ini adalah teknik observasi, wawancara dan studi dokumenter. Observasi, peneliti melakukan pengamatan secara langsung dan mencatat kegiatan dalam proses pembelajaran kewirausahaan. Pengamatan dilakukan terhadap perilaku dan skills peserta didik didalam melaksanakan tugas-tugas kelompok, pengembangan ide usaha, observasi lapangan dan presentasi laporan tugas, persiapan dan penyusunan rencana usaha, aksi dan kompetisi usaha. Wawancara dilakukan terhadap pendidik dan peserta didik untuk

\footnotetext{
${ }^{5}$ M.B , Miles \& Huberman A.Mikel. (Jakarta: Qualitative Data Analisis, 1992), hlm. 19
} 
menemukan permasalahan, kendala, dan pendapatnya terhadap pelaksanaan pembelajaran kewirausahaan.

Metode dokumenter, mencakup dokumen tertulis berupa hasil penilaian kinerja kelompok dalam kegiatan obseravasi lapangan, presentasi ide usaha dan perencanaan usaha, serta aksi dan kompetisiusaha berdasarkan instrumen penilaian yang tersedia, serta gambar (foto), yang dapat memberikan informasi tentang pelaksanaan proses pembelajaran kewirausahaan. Triangulasi data, metode, dan peneliti dilakukan untuk menguji validitas dan reliabilitas data.

\section{HASIL PENELITIAN DAN PEMBAHASAN}

\section{Pembelajaran Kewirausahaan}

Dalam implementasi pembelajaran Prakarya dan Kewirausahaan di SMKN 1 Sakra ini, peserta didik menerapkan Model Pendidikan karakter sebagai bentuk pengintegrasian nilai-nilai karakter, soft skills transferable skills yang dituangkan dalam bentuk Model Pengintegrasian Nilai-nilai karakter, soft skill dan transferable skill dalam pembelajaran kewirausahaan seperti terlihat pada Gambar 1, berupa tahapan-tahapan (sintaks) proses pembelajaran yang terdiri dari lima tahapan pembelajaran. Proses pembelajaran untuk penanaman nilai-nilai karakter dilaksanakan melalui pembiasaan sikap berani, respek, sportif. Pembentukan soft skills dan transferable skills dilakukan melalui latihan-latihan administrative skill, counseling skill, change skill, problem solving skill, dan customer service skill. Komponen-komponen nilai-nilai karakter dan latihan-latihan tersebut merupakan significant content skills yang perlu dan mendesak dikuasai oleh peserta didik dalam membentuk karakter dan berjiwa wirausaha.

\section{Kerangka Model Pendidikan Karakter dalam pembelajaran kewirausahaan}

untuk mengintegrasikan nlai-nilai karakter dan soft skills-transferable skills dituangkan dalam Gambar 1. 


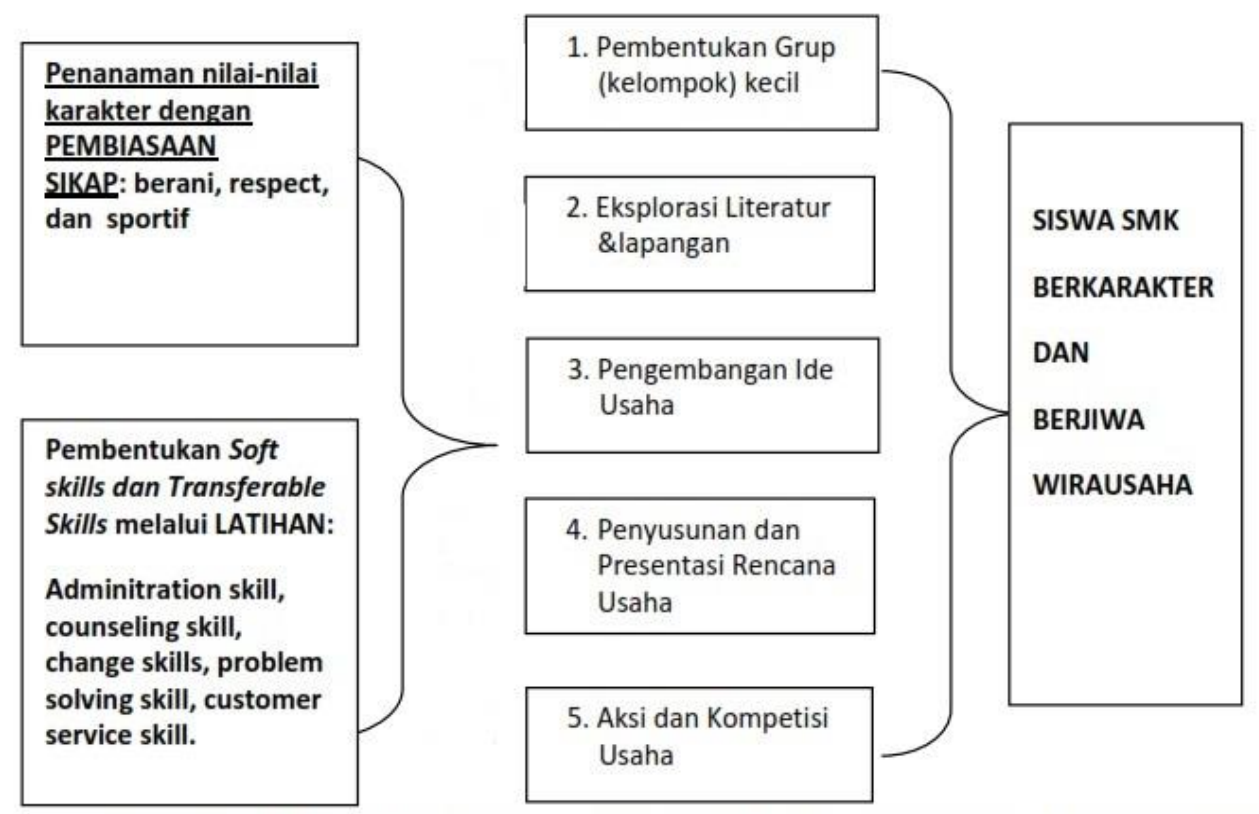

Gambar 1. Model Pengintegrasian Nilai-nilai Karakter, Soft Skill dan Transferable Skill dalam Pembelajaran Kewirausahaan.

Pembentukan karakter peserta didik di SMKN 1 Sakra, dilaksanakan melalui pembiasaan pembiasaan yang dilakukan peserta didik dan ditanamkan melalui peraturan-peraturan sekolah. Hasil observasi lapangan terhadap situasi di sekolah menunjukkan karakter yang ditanamkan melalui kebiasaan-kebiasaan di sekolah, tampak jelas diterapkan dengan baik antara lain respek kepada orang lain yang ditunjukkan peserta didik dengan, senyum, sapa/ucapan salam, anggukan kepala, kepada semua tamu. Sebelum memulai dan sesudah pelajaran usai "selamat pagi, selamat siang, Assalamuallaikum (untuk peserta didik muslim) dan salam sejahtera bagi kita semua (untuk peserta didik non-muslim)". Tidak lupa ucapan terima kasih disampaikan peserta didik kepada para pendidik setelah menyelesaikan pembelajarannya. Semua warga sekolah menerapkan kebiasaan senyum dan sapa ketika saling bertemu.

Kebiasaan sportif ditanamkan dalam aturan sekolah dalam bentuk sebelum pelajaran dimulai, ketua kelas mengumpulkan semua handphone milik peserta didik di kelas untuk diserahkan ke pendidik piket yang berada di kantor sekolah dan akan diambilnya kembali ketika pelajaran sudah usai. Bagi peserta didik yang terlambat masuk kelas, mereka akan langsung menghadap pendidik piket untuk lapor dan memberikan alasan keterlambatannya. Setelah mengisi dan mendapatkan surat keterangan dari pendidik piket, peserta didik diperbolehkan untuk memasuki dan mengikuti pelajaran yang sedang berlangsung. Keberanian ditanamkan kepada peserta 
didik pada kebiasaan untuk secara bergilir memimpin upacara sekolah, memimpin kelas, memimpin kelompok. Keberanian yang sudah ditanamkan oleh sekolah ini ditunjukkan oleh para peserta didik ketika melaksanakan pembelajaran praktik kewirausahaan dengan lima (5) tahapan proses pembelajaran, yaitu (1) Pembentukan Grup kecil, (2) Explorasi, (3) Pengembangan Ide Usaha, (4) Menyusun dan Presentasi Rencana Usaha, dan (5) Aksi dan Kompetisi Usaha. Tahapan pembelajaran kewirausahaan berlangsung sebagai berikut.

\section{Tahap Pembentukan Kelompok kecil (Small Group Building)}

Jumlah peserta didik kelas XII Bidang Keahlian Pemasaran SMKN I Sakra berjumlah tiga puluh satu (31) dibagi menjadi enam kelompok. Pembentukan kelompok berdasarkan pada heterogenitas karakteristik kemampuan peserta didik yang selama ini sudah diterapkan oleh pendidik sekolah. Seperti yang dinyatakan pendidik kewirausahaan:" Saya sudah membagi peserta didik saya menjadi enam (6) kelompok sesuai dengan karakteristik kemampuan mereka, sehingga mereka bisa bekerja sama dengan baik".

Kemampuan bekerja dalam tim nampak sekali dalam setiap kegiatan proses pem- belajaran kewirausahaan. Hal ini didukung dengan pernyataan peserta didik partisipan; "kelompok kami kompak dan bekerja sama dengan baik bu.dalam setiap kegiatan“. Kerja sama yang menonjol dalam kegiatan diskusi kelompok membahas materi di kelas maupun di lapangan ketika melakukan observasi lapangan, mereka saling menghargai (respect) terhadap pendapat teman-teman kelompok, menghargai dan menghormati wirausahawan yang diwawancarai, membuat para peserta didik berani untuk mengemukakan pendapat. Hasil observasi menunjukkan diskusi peserta didik berlangsung ramai, saling adu argumen dan menyatakan pendapatnya masingmasing sebelum mereka menyepakati bersama ide mereka.

Dengan demikian, kelompok-kelompok diskusi dan belajar yang sudah terbentuk sebelum studi eksplorasi menumbuhkan sikap kerja sama dan kekompakan tumbuh dengan baik. Nilai-nilai karakter, soft skills dan transferabel skills yang ingin dibentuk dalam kegiatan kelompok ini adalah kemampuan untuk berdiskusi, berpendapat maupun meminta pendapat dan bertanya (driving question and need to know), menghargai pendapat orang lain, menghargai aturan main yang sudah 
ditetapkan pendidik, memecahkan permasalahan bersama dan menyepakati keputusan bersama yang telah dipilih dari berbagai alternative solusi (voice and choice), setelah dilakukan revisi dan refleksi (revision and reflection). Semua kegiatan dalam kelompok ini akan membentuk perilaku berani, respek, sportif dan administrative skills, counseling skills, problem solving skills, change skills. Kegiatan kelompok berlangsung sampai dengan akhir pembelajaran.

Tahap Eksplorasi (Exploration) Kegiatan Eksplorasi dimulai di dalam kelas dengan memperhatikan materi kewirausahaan, mengkaji konsep dan contoh dengan bertanya untuk memahami permasalahan dan melakukan identifikasi terhadap masalah yang dihadapi. Pendidik memberikan motivasi dengan memutarkan video tentang succes story para pengusaha. Peserta didik menyimak dengan baik dan mencermati hal-hal apa saja yang menarik dari kisah perjalanan sukses sang pengusaha dengan perjuangannya untuk meraih mimpinya. Fighting spirit yang dilakukan untuk mengatasi setiap kegagalan yang dialami, karakteristik dan kiat-kiat sukses adalah yang perlu diperhatikan, didiskusikan, dan disimpulkan oleh setiap kelompok peserta didik.

Para peserta didik tampak senang diajak nonton video bersama, suasana kelas menjadi ramai senang ketika pendidik memberi tahu; “ Anak-anak..kita sekarang akan menonton video bersama... tentang kisah sukses seorang pengusaha..Kita akan melihat kisah perjuangannya mulai dari sejak susah hidupnya sampai menjadi orang yang sukses!” . Dengan mencermati setiap kisah perjuangan meraih sukses dari para pengusaha dan memberikan tugas untuk mengkritisi, pendidik melatih peserta didik untuk berpikir kritis, berani mengemukakan pendapat, memecahkan masalah dan mengambil keputusan.

Sementara itu kelompok peserta didik juga diminta untuk berdiskusi dan menuangkan ide-ide usaha yang akan dirancang dan dikembangkan berikutnya. Dengan mencermati video kisah perjalanan sukses, peserta didik diharapkan terinspirasi dan juga termotivasi untuk berwirausha. Tugas berikutnya pendidik meminta para peserta didik secara berkelompok melakukan observasi lapangan ke tempat wirausahawan sukses agar lebih mengenal dan mencari sumber belajar langsung kepada pelaku usaha di luar kelas. Peserta didik melakukan observasi, wawancara dengan para wirausahawan untuk mendapatkan pengetahuan, 
pengembangan ide usaha dan proses pelaksanaan usaha kerajinan (sesuai dengan bidang usaha yang ditentukan di sekolah) dan ide usaha yang akan dikembangkan.

Instrumen observasi berisi poin-poin tentang apa yang harus ditanyakan kepada wirausahawan sudah disiapkan pendidik. Beberapa peserta didik menyatakan bahwa:" Dengan adanya petunjuk penilaian observasi ini, kami mudah untuk menyiapkan pertanyaan apa saja yang ingin kami tanyakan kepada bapak pengusaha itu Bu...” Observasi lapangan dilukan para peserta didik selain untuk membentuk karakter berani bertemu dan berkomunikasi dengan orang lain (public audience), jugauntuk menghormati profesi wirusaha serta sportif untuk melaksanakan tugas yang sudah diberikan oleh pendidiknya. Seperti yang dinyatakan oleh seorang peserta didik; " awalnya saya tidak berani atau ragu apakah saya bisa menemui dan mewawancarai pengusaha itu bu.... takut...tapi karena kita berkelompok jadi... berani saya untuk bertemu bapak itu! (maksudnya pengusaha). Peserta didik yang lain ada yang berkomentar;" Wah jadi pengusaha itu enak ya Bu...kaya..dan bisa menjadi Boss".

Tugas observasi lapangan diberikan untuk mendapatkan ide-ide kreatif dengan melakukan pengamatan, mewawancarai dan mengetahui bagaimana proses pembuatan, memasarkan, dan mengelola usaha. Rekapitulasi skor observasi lapangan menunjukkan bahwa para peserta didik sudah melaksanakan kegiatan observasi lapangan dengan baik yang ditunjukkan dengan skor penilaian di atas 20 dari skor maksimum 30. Tiga (3) kelompok mendapatkan skor 24, Satu (1) kelompok dengan skor 26 dan dua (2) kelompok dengan skor 27.

\section{Tahap Pengembangan Ide Usaha ( Business Idea Development)}

Hasil observasi lapangan ke tempat wirausaha sukses dan diskusi kelompok, memunculkan ide usaha yang akan dikembangkan peserta didik. Kelompok pertama, "Woody Hand- made" (kerajinan dari bahan limbah kayu dan bambu); kelompok ke dua, " Little Hand made" (kerajinan boneka mini dan bunga dari limbah plastik; kelompok ke tiga "Avikali Handy craft" (kerajinan rangkaian bunga dari bahan serbuk sabun); kelompok ke empat "Calika Accesories" (kerajian berbagai ma- cam acsesories dari limbah plastik); kelompok ke lima "Brown Led"(kerajinan dari bahan limbah akar dan bonggol tanaman); dan kelompok ke 
enam "Djafa Lampions" (ke-rajian lampu hias dari limbah sendok plastik dan tutup botol bekas). Pengembangan ide usaha merupakan kegiatan yang harus dilakukan oleh para pe- serta didik setelah melakukan kegiatan observasi lapangan ke tempat wirausaha sukses dibidang usaha yang ingin dikembangkannya.

Diharapkan dengan kegiatan ini, para peserta didik telah memiliki ide usaha yang mantap akan dikembangkan ke depan dan mulai menyusun proposal usaha. Aspek penilaian yang dilakukan di sini antara lain para peserta didik melakukan analisis terhadap ide yang akan dikembangkan, yaitu mengenai (1) sumber ide darimana para peserta didik memperolehnya, (2) analisis kebutuhan pasar, (3) kreativitas ide, (4) kekuatan (strong), (5) kelemahan (weakness), (6) peluang (opportunity), dan (7) tantangan (threat). Rekapitulasi hasil penilaian tiap kelompok usaha di SMKN I Sakra menunjukkan bahwa kelompok "Woody Handmade" memiliki skor yang pa- ling tinggi dalam pengembangan ide usahanya.

Kelompok ini membuat kerajinan dari bahan limbah kayu yang dibuat menjadi miniature rumah dilengkapi perabotan dan diberi lampu 5 watt yang bisa berfungsi sebagai lampu tidur. Pohon jati banyak tumbuh di daerah mereka, yang digunakan untuk berbagai macam bahan bangunan, perabot furniture, dan kerajinan lainnya. Sedangkan sisa limbahnya dimanfaatkan oleh peserta didik kelompok "woody handmade" untuk mem- buat kerajinan, selain miniature rumah, juga membuat hiasan tempat pensil, asbak, vas bunga dan lain-lain.

Kreativitas dan kekompakan kerja sama mereka untmenghasilkan ide pengembangan karya kerajinan yang dibutuhkan oleh masyarakat dengan memanfaatkan limbah yang tidak terpakai, seperti yang telah mereka ungkapkan dalam presentasi pengembangan ide usaha "kami memanfaatkan limbah kayu yang sudah tidak terpakai untuk membentuknya menjadi barang-barang yang menarik untuk menjadi hiasan yang fungsional".

Hal ini menjadi point lebih dari penilaian terhadap mereka. Kegiatan pengembangan ide usaha ini merupakan kegiatan yang penting untuk memulai membentuk usaha sebelum para peserta didik menyusun rencana usaha yang akan dilakukan. Ide-ide kreatif berkembang sete- lah hasil diskusi kelompok mendapatkan pencerahan, pengembangan dan pematangan dalam kegiatan observasi lapangan serta wawancara yang dilakukan terhadap para wira- usahawan sukses. 
Temuan menunjukkan bahwa, proses amati, tiru dan modifikasi dengan sentuhan kreatif tidak bisa dihindari di sini. Seperti kerajinan membuat bunga plastik dengan pernak- perniknya, bunga yang terbuat dari serbuk sabun mandi dicampur bahan- bahan pewarna dan perekat dengan kombinasi aksesories daun, batang dan pemilihan vas yang sesuai, dan kerajinan kayu bekas dan pelepah bunga tebu yang dibentuk miniaturrumah dengan isi perabotan sebagai aksesorisnya.

Produk-produk peserta didik ini kebanyakan memodifikasi karya-karya yang sudah ada, kemudian memberikan sentuhan kreatif. Temuan lain menunjukkan, bahwa potensi bahan yang melimpah dari lingkungan sekitar peserta didik yang tidak termanfaatkan, akan memunculkan kreativitas untuk membuat sesuatu yang bernilai guna.

\section{Tahap Penyusunan dan Presentasi Rencana Usaha (Prepare and Presentation Business Plan)}

Kegiatan Penyusunan dan Presentasi Rencana Usaha adalah kegiatan uji kelayakan dari ide usaha yang akan dilaksanakan dengan melalui proses bimbingan dan diskusi kemudian mempresentasikan rencana usahanya di depan kelas. Pendidik dan pengamat (peneliti) serta para peserta didik yang tergabung dalam ke- lompokkelompok usaha saling mengkritisi dan memberi saran untuk penyempurnaan proposal usaha yang telah di susun. Temuan menunjukkan bahwa sebagian besar kelompok peserta didik tidak memasukkan komponen biaya (honorarium) pegawai atau tenaga kerja yang telah dikeluarkan untuk memproduksi usaha tersebut. Mereka kurang tahu untuk memperhitungkan tenaga kerja yang dikeluarkannya harus dimasukkan dalam biaya usaha.

Beberapa peserta didik ada yang mengatakan; “ Bu, karena ini usaha baru maka kami tidakmemperhitungkan honor untuk kami, nanti kalau sudah berkembang baru diperhitungkan". Ada yang menghitung harga produknya terlalu murah. Selain tidak menghitung honorarium pekerja, bahan baku produksi diambil dari rumah sendiri. Apalagi untuk bahan yang menggunakan limbah yang tidak membutuhkan biaya Contoh: akar pohon yang diambil dari halaman rumah, limbah kayu bekas, limbah plastik. Presentasi rencana usaha berjalan dengan tertib dan lancar. 
Setiap kelompok meminta untuk mendapatkan kesempatan mempresentasikan rencana usahanya, walau rencana semula hanya akan dilakukan sampel random mengingat waktu yang tersedia. Mereka menggunakan kesempatan presentasi untuk mendapatkan masukkan dari rencana usaha yang dibuat. Semangat dan antusiasme para peserta didik menunjukkan kesadaran yang tinggi untuk mau menerima masukan dan kritikan serta keberaniannya untuk majudapat dan menjawab pertanyaan dengan baik.

Respek juga ditunjukkan dengan penghargaannya terhadap pendapat orang lain maupun teman-teman kelompoknya sehingga tercapai kesepakatan bersama dan penyempurnaan dari proposal usahanya. Penyusunan dan presentasi proposal usaha merupakan sarana untuk melatih nilai-nilai karakter dan soft skills-transferable skills yang mereka miliki. Keberanian, respek, sportif dan administratif skills, counseling skills, problem solving skills, change skills, customer service skills yang dalam prosesnya nanti akan terakumulasi dalam kegiatan praktik usaha dan kompetisi usaha sehingga akan berhasil melaksanakan pembelajaran kewira- usahaan dan berwirausaha.

\section{Tahap Aksi dan Praktik dan Kompetisi Usaha (Action and Competition).}

Kegiatan praktik dan Kompetisi Usaha merupakan tahapan akhir dari proses pengintegrasian nilai-nilai karakter, soft skills dan transferable skills dalam mata pelajaran prakarya dan kewirausahaan. Diharapkan dalam tahapan ini menunjukkan hasil yang positiingga akan menghasilkan lulusan SMK yang berkarakter dan berjiwa wirausaha. Aspek-aspek yang dinilai dalam praktik dan kompetisi usaha ini adalah; kreativitas ide, volume penjualan, pemasaran (4P) price, product, promotion, dan place, manajemen keuangan, administrasi usaha, prospek pengembangan usaha, dan laporan hasil usaha. Hasil penilaian praktik dan kompetisi usaha menunjukkan kelompok "Avikalila Handy- craft” mendapatkan skor tertinggi sebanyak 27, diikuti kelompok "Brown LED" 26, "Woody handmade" 25, "Djafa lampion" 24, "Little handmade" 23, dan terendah keloppok" Calika" dengan skor 22.

Kegiatan praktik usaha dan kompetisi usaha dilaksanakan di luar dan di dalam sekolah. Kegiatan praktik usaha di dalam sekolah sudah mulai terasa sehari sebelum kegiatan dengan kesibukan para peserta didik mempersiap- kan tempat dan peralatan, 
serta barang-barang yang akan di display dalam stand-stand yang dibuat oleh mereka. Keceriaan tampak di wajah mereka, semangat untuk berkreasi dan berkompetisi ditampakkan dengan banyaknya kreasi-kreasi yang dihasilkan. Kegiatan penjualan produk juga di lakukan di luar sekolah dengan cara “door to door" ke kantor-kantor dan rumah-rumah disekitar sekolah.

Kegiatan penjualan ke luar sekolah adalah untuk melatih mental, keberanian, dan mengasah keterampilan dalam melayani konsumen dari berbagai macam latar belakang sosial, pendidikan, ekonomi. Berdasarkan hasil pengamatan peneliti, semangat para peserta didik di dalam menjual, mempromosikan, dan melayani konsumen sangat membanggakan. Menurut pendapat para peserta didik, ini adalah pengalaman yang menarik dan menyenangkan. Mereka mengatakan "exited! walaupun capek, ini pengalaman baru kami yang menantang sekaligus menyenangkan bu!".

Kegiatan dilakukan mulai pk.8.00 pagi sampai pk.14.00 baru kembali ke kelasnya masing-masing. Dari enam kelompok usaha, ada satu usaha "avikalila handycraft" yang memproduksi bunga dari bubuk sabun yang dicam- pur dengan bahan pewarna dan lem serta bahan pelengkap bunga seperti daun dan batang serta vas yang sesuai, sudah memperoleh pesanan dari konsumen pembeli. Para peserta didik diarahkan oleh pendidik untuk membuka web. site untuk melayani promosi dan pemesanan oleh konsumen. Dalam kegiatan aksi dan kompetisi ini, setiap kelompok diberi bantuan masing- masing Rp. 200,000. sebagai modal usaha. Selain itu diberikan stimulan hadiah bagi para pemenang kompetisi usaha untuk Juara 1, 2, dan 3.

Namun untuk memberikan motivasi kepada semua kelompok, pendidik memutuskan untuk membagi hadiah kepada semua kelompok sesuai dengan urutan juara $1,2,3,4,5$, dan 6 . Hal ini diterima dengan senang hati oleh para peserta didik.

\section{KESIMPULAN}

Hasil ekplorasi terhadap pengalaman peserta didik dalam implementasi model "Pendidikan Karakter" dalam pembelajaran kewirausahaan menunjukkan bahwa pembiasaan atau habituasi karakter santun, berani, respek, sportif, tanggung jawab sudah ditanamkan dan dilaksanakan oleh pihak Sekolah (SMKN 1 Sakra) melalui penerapan peraturan dan disiplin peserta didik dalam berperilaku dan kegiatan di 
sekolah. Penanaman nilai-nilai karakter dalam proses pembelajaran kewirausahaan sebaik-nya ditanamkan sejak dini. Untuk pembelajaran Kewirausahaan di SMK bisa dimulai sejak di kelas sepuluh (X).

Penanaman nilai-nilai karakter sejak dini akan membentuk habit (kebiasaan) berperilaku. Implementasi model "Pendidikan Karakter", perilaku baik sebagai bentuk tertanamnya karakter berjiwa wirausaha, bersamaan dengan latihan-latihan soft skills-transferable skills terintegrasi dalam setiap tahapan pembelajaran kewirausahaan.

Dengan tahapan-tahapan kegiatan yang sudah disiapkan dengan baik akan membantu peserta didik dan pendidik dalam mengintegrasikan nilai-nilai karakter,softskills-transferable skills sehingga dengan proses pembiasaan dan latihan akan terbangun karakter dan jiwa wirausaha. Untuk terus tumbuh dan berkembang, ini memerlukan proses dan waktu yang panjang dan berkelanjutan. Pemilihan bidang usaha dalam mata pelajaran prakarya dan kewirausahaan yang ditentukan oleh sekolah yang disesuaikan dengan potensi daerah atau lingkungan sekolah (kearifan lokal) akan memberikan hasil yang lebih baik dalam usaha penanaman dan penumbuhkembangan jiwa wirausaha, serta memunculkan ide-ide kreatif untuk mengembangkan usaha.

Dalam menyusun rencana usaha, para peserta didik masih belum memperhatikan biaya yang harus dikeluarkan untuk honorarium kelompok kerja usaha mereka Seandainya ada, mereka memberikan jumlah nominal yang kecil atau kurang bisa menghargai tenaga sendiri.

\section{DAFTAR PUSTAKA}

Endang Mulyani, dkk. 2010. Pengembangan Pendidikan Kewirausahaan, Jakarta: Pusat Kurikulum, Badan Penelitian dan Pengembangan, Kementrian Pendidikan Nasional,

Samani Muhlas \& Hariyanto, 2011. Konsep dan Model Pendidikan Karakter. Bandung: Rosdakarya

Hidayatullah, M. F. (2010). Pendidikan karakter: membangun peradaban bangsa. Surakarta: Yuma Pustaka

Muhammad Nuh, 2010. Desain Induk Pendidikan Karakter kementrian Pendidikan

Nasional. Jakarta: Kementrian Pendidikan Nasional.

M.B , Miles \& Huberman A.Mikel. 1992. Qualitative Data Analisis 